Note

\title{
The American Invention of Child Support: Dependency and Punishment in Early American
}

\section{Child Support Law}

\section{Drew D. Hansen}

In modern American politics, "child support" is almost always mentioned in the same sentence as "welfare reform." When the Clinton Administration dramatically overhauled the nation's welfare system during the summer of $1996,{ }^{1}$ politicians from both parties praised the new law's child support provisions. President Clinton hailed the possibility that child support enforcement might shrink welfare rolls. "If every parent paid the child support they should," he said at the news conference following the signing of the bill, "we could move 800,000 women and children off welfare immediately." ${ }^{2}$ At the parallel Republican press conference, Representative Jennifer Dunn pointed out that nonpayment of child support was a major cause of welfare dependency. Reminding her audience that over thirty billion dollars in court-ordered child support payments goes uncollected, she asked: "What happens when that money is not paid? The children and the mother go on welfare. And so the taxpayer becomes in effect the parent of those children." 3

The villain in the child support reform story is the "deadbeat dad" who does not pay child support. In a speech in Denver one week before he signed the welfare bill, President Clinton assured his audience that nonpayment of child support was a serious crime, comparing it to robbing a

1. See Personal Responsibility and Work Opportunity Reconciliation Act of 1996, Pub. L. No. 104-193, 110 Stat. 2105 (to be codified as amended in scattered sections of 42 U.S.C.).

2. The Welfare Bill: Text of President Clinton's Announcement on Welfare Legislation, N.Y. TMIES, Aug. 1, 1996, at A24.

3. The Welfare Bill: The Republicans' View, N.Y. TImEs, Aug. 1, 1996, at A25. 
bank or a 7-Eleven store. ${ }^{4}$ In a final cascade of warnings to "deadbeat dads," the President said: "[I]f you owe child support, you better pay it. If you deliberately refuse to pay it, you can find your face posted in the Post Office. We'll track you down with computers .... We'll track you down with law enforcement. We'll find you through the Internet." 5

These remarks by President Clinton and Representative Dunn illustrate two aspects of the modern American political discourse about child support. First, child support enforcement is an anti-dependency measure. ${ }^{6}$ Politicians want to enforce child support orders because they are worried that the country is spending too much money on welfare and because they think that increasing child support collections will lower poverty rates among single mothers. Second, nonpayment of child support is a serious crime that should be punished by the criminal law. Americans today conceptualize child support in terms of preventing dependency and in terms of punishing those who "cause" dependency.

These preoccupations have important practical consequences for the functioning of the American child support system. Consistent with a focus on preventing dependency, child support awards in America are often just high enough to enable a single mother to avoid welfare, but not high enough to ensure that her children obtain an adequate standard of living. However, one need not think about child support solely in terms of preventing dependency. One could imagine, for example, a child support system with a stated goal of providing an adequate standard of living for children of any economic status. The practical consequences of this shift in mindset might be the institution of higher child support awards and the expansion of governmental supports for all parents with young children-

4. See William J. Clinton, Remarks Made to the Citizens of Denver (July 18, 1996), in U.S. NEwSwIRE, July 23, 1996, available in LEXIS, Nexis Library, Curnws File.

5. Id.

6. In this Note, I use the term "dependency" to refer to both the economic condition of poverty and the sociological condition of being dependent on public aid. See generally Nancy Fraser \& Linda Gordon, A Genealogy of Dependency: Tracing a Keyword of the U.S. Welfare State, 19 SIGNS 309 (1994) (charting the history of the term "dependency" and noting its ability to impose moral connotations of unworthiness on recipients of public aid).

7. See ANDREA H. BELlER \& JoHN W. GRAHAM, SMALl CHANGE: THE ECONOMICS OF CHILD SUPPORT 106 (1993) (analyzing Census Bureau data on child support awards from 1978 to 1985 and concluding that "not only does the average level of child support awards seem to be too low, but increments to awards with increases in the number of children due support are also too low to meet the needs of most families"); Welfare Reform Proposals, Including H.R. 4605, The Work and Responsibility Act of 1994: Hearings Before the Subcomm. on Human Resources of the House Comm. on Ways and Means; 103d Cong. 633 (1994) (statement of Nancy Duff Campbell, Co-President, National Women's Law Center) (noting that the average annual award collected in 1989 among one-child families was $\$ 2995$, while the average annual cost of raising a child ranged from $\$ 4030$ to $\$ 5520$ ). 
perhaps something along the lines of the $\$ 500$ per child tax credit enacted in $1997 .^{8}$

Similarly, a focus on punishing "deadbeat dads" need not drive the American understanding of how to make it easier for single mothers to raise their children. Certainly, fathers should be made to contribute to their children's upbringing; but some fathers do not have the financial ability to pay more than trivial amounts of child support. ${ }^{9}$ A narrow focus on punishing nonsupporting fathers without any measures to make it easier for poor fathers to make regular child support payments might be an appealing symbolic way to enforce personal responsibility, but it does little to promote the welfare of American children.

This dependency-punishment framework is not the only way that we could think about child support. We could, for instance, take national responsibility for child support in the way that we take national responsibility for the care of the elderly through programs such as Social Security and Medicare. ${ }^{10}$ But while the United States government assists families with childrearing costs in a variety of ways-through the tax exemption for dependents, ${ }^{11}$ for example, and through the Earned Income Tax Credit ${ }^{12}$-America lacks a serious national commitment to ensuring that all children receive adequate economic support. ${ }^{13}$

Why do Americans think that child support should be governed by concerns about dependency and punishment? In this Note, I argue that our current dependency-punishment framework for understanding child support is rooted in the invention of a legally enforceable child support obligation by American courts in the nineteenth century. ${ }^{14}$ Early American child support law developed in two phases. In the first phase, nineteenth-century American judges invented a civil child support obligation because of their

8. See Taxpayer Relief Act of 1997, tit. I, Pub. L. No. 105-34, 111 Stat. 788 (to be codified as amended at 26 U.S.C. § 24 ).

9. See JYL J. JOSEPHSON, GENDER, FAMIIIES, AND STATE: CHIID SUPPORT POLICY IN THE UNTTED STATES 96-98 (1997); Harry D. Krause, Child Support Reassessed: Limits of Private Responsibility and the Public Interest, in DIVORCE REFORM AT THE CROSSROADS 166, 175 (Stephen D. Sugarman \& Herma Hill Kay eds., 1990).

10. Cf. The News Hour with Jim Lehrer (PBS television broadcast, Jan. 13, 1997), available in LEXIS, Nexis Library, Curnws File (interview with Professor Theda Skocpol) (describing Social Security as a "shared security" program that embodies a national commitment to guarantee benefits to elderly Americans).

11. See 26 U.S.C.A. \$ 151(c) (West 1998).

12. See id. $\$ 32$.

13. See Martha L.A. Fineman, Masking Dependency: The Political Role of Family Rhetoric, 81 VA. L. REV. 2181, 2203 (1995) ("Unlike other industrialized democracies we have no welldefined notion of collective responsibility for inevitable dependency .... In fact, recent welfare reforms resort to the privatized solutions of marriage or child support as the answer for myriad societal problems, including child poverty.").

14. Throughout this Note, I will be referring to the judicial and legislative invention of child support duties for divorced fathers. The imposition of child support obligations on never-married fathers occurred through the so-called bastardy or illegitimacy laws, a development that I discuss infra notes 120-122 and accompanying text. 
concerns about dependency among single mothers and their children. The judges who created a child support obligation were motivated both by a desire to help needy single mothers and by a belief in conserving the poorrelief system's resources by shifting the responsibility for aiding these families onto nonsupporting fathers. In the second phase, many states in the late nineteenth century enacted criminal nonsupport statutes to force fathers to provide for their wives and children. The twin discourses of dependency and punishment drove both the civil and criminal regimes, and they eventually came to dominate modern understandings of child support. In fact, one of the most significant differences between the nineteenth-century child support system and the modern one is not the general framework of dependency and punishment, but the modern addition of a racially inflected blaming of African-American fathers and mothers for welfare dependency. ${ }^{15}$

In Part I of the Note, I situate the American invention of child support in the socio-legal context of the emergence of economically vulnerable single-mother households and the growing inability of the traditional poorrelief system to cope with these families' needs.

In Part II, I analyze the American invention of child support. I trace the development of this body of law from its antecedents in the "natural duty" of child support at English common law to the self-conscious legal creativity of the American courts that invented a child support obligation in response to dependency among female-headed households. I end Part II with a consideration of the child support issues faced by black families, noting how both limitations on marriage among blacks and white Americans' racist views of black children contributed to the emergence of distinct child support issues in the nineteenth-century black community.

In Part III, I outline the beginnings of criminal sanctions for nonpayment of child support. I trace the origins of these laws to the English Poor Law of 1601 and its American counterparts. The failures of the poor laws in America, largely caused by the social changes outlined in Part I, helped motivate reformers to enact criminal nonsupport statutes in the $1870 \mathrm{~s}$ and 1880s. These statutes completed the move toward the current paradigm of thinking about child support by adding a punitive edge to concerns about causing dependency. In the Conclusion, I critique some of the modern consequences of the dependency-punishment paradigm of child support. I specifically consider how the dependency-punishment paradigm

15. Because the primary focus of the Note is the invention of a common law and statutory child support obligation in the 19th century by American courts, a system open only to white Americans for most of the century, the emphasis that I can place on the historical experience of African-American families is necessarily limited. I have outlined the general contours of the child support issues faced by black families in the 19th century infra Section II.C as a backdrop to my consideration infra Part IV of how racial attitudes have affected the modern child support system. 
has remained constant from the nineteenth century to the twentieth century, while noting how the twentieth-century application of this paradigm focuses particularly on blaming African-American mothers and fathers for welfare dependency. I end the Note by presenting some thoughts on how the nineteenth-century child suport obligation might have played some role in diminishing pressure for family allowances in early twentieth-century America.

\section{THE SOCIAL CONTEXT OF EARLY AMERICAN CHILD SUPPORT LAW}

Several social and legal transformations during the nineteenth century led to an increase in single motherhood. In this Part, I outline how changes in the legal regime surrounding divorce and child custody interacted with social changes in the meaning of childhood to cause a rise in the number of divorced mothers who were expected to nurture and care for their children. During the same period, family desertion emerged as a major social problem, as wage-earning men who could not access the courts to obtain divorces simply left their wives. The colonial poor-relief system was breaking down at the same time, making it difficult for towns to cope with the demands for relief posed by this new class of single mothers and their children.

\section{A. Transformations in Divorce and Child Custody in Nineteenth-Century America}

During the nineteenth century, American society witnessed a sharp rise in the number of single mothers with young children. The rise in the divorce rate, the emergence of maternal preference in child custody, and the new value placed on childrearing combined to make it difficult for single mothers to support their children without relying on local poor-relief.

\section{Transformations in Divorce Law}

Divorce was relatively rare in colonial America. ${ }^{16}$ The divorce rate increased steadily during the nineteenth century, ${ }^{17}$ however, in response to

16. See, e.g., MARY SOMERVLLE JONES, AN HistoriCAL GEOGRAPHY OF THE CHANGING DIVORCE LAW IN THE UNITED STATES 17-21 (1987) (noting that Connecticut had 390 divorces between 1738 and 1788, that Massachusetts had 96 divorces between 1760 and 1786, and Georgia had 291 divorces between 1798 and 1835); Nancy F. Cott, Divorce and the Changing Status of Women in Eighteenth-Century Massachusetts, in THE AMERICAN FAMIL Y IN SOCIAL-HISTORICAL PERSPECTIVE 115, 118 (Michael Gordon ed., 2d ed. 1978) (noting an increase in the number of divorce petitions filed throughout the 18th century in Massachusetts). 
the liberalization of divorce laws in most states,${ }^{18}$ the transfer of jurisdiction over divorce from the legislatures to the courts, ${ }^{19}$ and social changes such as industrialization and rising expectations of marriage that led more Americans to take advantage of those laws. ${ }^{20}$ The pace of the rise in divorce varied by region, but by 1850 there was a clearly observable national trend toward marital breakdown. ${ }^{21}$

Women often successfully sued for divorce in the nineteenth century by charging their husbands with fault in causing the divorce. ${ }^{22}$ The most common grounds for divorce among women in the nineteenth century were desertion ${ }^{23}$ or cruelty on the part of their husbands. ${ }^{24}$ By the end of the

17. For a general history of divorce during this period, see RICHARD H. CHUSED, PRIVATE ACTS IN PUBlic Places: A SOCIAL History OF DivorCE IN THE Formative ERA OF AMERICAN FAMILY LAW (1994); and GLENDA RILEY, DIVORCE: AN AMERICAN TRADITION (1991).

18. The pace of divorce law liberalization varied by region. The northeastern states were the first to include more grounds for divorce in their laws, with most states liberalizing their laws before 1850 . The mid-Atlantic states expanded their grounds for divorce around 1850 , slightly later than the northeastern states did. The South remained basically conservative throughout the century. Beginning in the second quarter of the 19th century, the settlement of the new states in the West such as Ohio and Indiana created a series of "divorce mills" with generous divorce laws and weak residency requirements for those seeking divorces. See JONES, supra note 16, at 20-24. Western states between 1776 and the mid-19th century granted more divorces than either their northeastern or their Southern counterparts. See RILEY, supra note 17, at 49.

19. By 1867, 33 of 37 American jurisdictions had substituted judicial for legislative divorce. See MichaEL GROSSBERG, GOVERNING THE HEARTH: LAW AND THE FAMILY IN NINETEENTHCENTURY AMERICA 251 (1985). Shifting jurisdiction to the courts often entailed more discretion in examining divorce cases than there had been under legislative divorce, often resulting in more liberal responses to divorce petitions. See RIIEY, supra note 17, at 42.

20. See CARL N. Degler, AT ODDS: WOMEN AND THE FAMILY IN AMERICA FROM THE REVOLUTION TO THE PRESENT 167-77 (1980); RILEY, supra note 17, at 55.

21. See RILEY, supra note 17, at 55. For divorce statistics after the Civil War, see id. at 79, which charts a $27.9 \%$ increase in divorce from $1867-1871$ to $1872-1876$ and a $30.3 \%$ increase in divorce from 1872-1876 to $1877-1881$.

22. See id. at 79 .

23. See JONES, supra note 16 , at 50 tbl.4. From 1867 to $1886,38.5 \%$ of all divorces in the American West were based on desertion ( $45.7 \%$ of men's, $34.7 \%$ of women's), and from 1887$1906,38.9 \%$ of all divorces were based on desertion ( $49.4 \%$ of men's, 33.6\% of women's). See RILEY, supra note 17 , at 87.

24. In particular, the charge of cruelty was rapidly becoming the ground of choice in mid-nineteenth-century America. New Hampshire had adopted the cruelty plea in 1791, Vermont and Rhode Island in 1798, Ohio in 1804, Kentucky in 1809, Pennsylvania in 1815, Delaware and Michigan in 1832, Iowa in 1839, Texas in 1841, and Kansas in 1855. By 1886, only six states refused to accept cruelty as a ground for divorce.

RILEY, supra note 17, at 81. See also Robert L. Griswold, The Evolution of the Doctrine of Mental Cruelty in Victorian American Divorce, 1790-1900, 20 J. SoC. HIST. 127 (1986) (documenting increased judicial acceptance of the cruelty ground for divorce in 19th-century America); Robert L. Griswold, Sexual Cruelty and the Case for Divorce in Victorian America, 11 SIGNS 529 (1986) (same). From 1867 to $1888,15.6 \%$ of divorces nationwide were based on cruelty (5.4\% of men's and $21 \%$ of women's), and from 1887 to $1906,21.8 \%$ of divorces were based on cruelty (10.5\% of men's and $27.5 \%$ of women's). See RILEY, supra note 17 , at 89. 
nineteenth century, divorce had become almost as significant as the death of a spouse as a cause for marital dissolution. ${ }^{25}$

\section{Transformations in the Role of Children}

The rise in divorces during the nineteenth century created a problem for nineteenth-century courts: What should be done about the children of divorced couples? $?^{26}$ The transformation in the role of children in American life that had begun around the turn of the century complicated the problem. For most of the eighteenth century, children were seen as small adults, valued mainly for their ability to contribute to the household economy. ${ }^{27}$ Beginning in the nineteenth century, this view of children as economic assets began to give way to a more romantic, idealized view of childhood among the middle and upper classes. ${ }^{28}$ By the 1830 s, there was a clearly established idea among middle and upper-class American whites that childhood was a distinct stage of life that required middle-class parents and teachers to exert special effort to care for young children. ${ }^{29}$

As a result of these changing views of childhood, child labor became less accepted in the American economy. As late as the 1810s, many factories employed children, with little apparent public outcry. ${ }^{30}$ But around

25. See J.E. GOLDTHORPE, FAMILY LIFE IN WESTERN SOCIETIES: A HISTORICAL SOCIOLOGY OF FAMILY RELATIONSHIPS IN BRITAIN AND NORTH AMERICA 43 fig.1 (1987) (charting the rise in divorces and the decline in deaths as causes of marital dissolution during the 19th century).

26. See infra Subsection I.A.3.

27. As one historian notes: "In labor-scarce America the services or wages of a child over ten was one of the most valuable assets a man could have." MARY ANN MASON, FROM FATHER's PROPERTY TO CHILDREN'S RIGHTS: THE HISTORY OF CHIID CUSTODY IN THE UNITED STATES 6 (1994); see also JOHN DEMOS, A LITTLE COMMONWEALTH 140-41 (1972) (noting colonial practices of apprenticing out children at the age of six to eight years); Ross W. Beales, Jr., Boys' Work on an Eighteenth Century New England Farm, in THE AMERICAN FAMILY: HISTORICAL PERSPECTIVES 75 (Jean E. Hunter \& Paul T. Mason eds,, 1991) (describing representative cases of child laborers).

28. See DEGLER, supra note 20, at 66-72; MiCHAEL B. KATZ, RECONSTRUCTING AMERICAN EdUCATION 10-11 (1987); JACQUELINE S. REINIER, FROM VIRTUE TO CHARACTER: AMERICAN CHILDHOOD, 1775-1850, at 72-73, 134-38 (1996); Jamil S. Zainaldin, The Emergence of a Modern American Family Law: Child Custody, Adoption, and the Courts, 1796-1831, 71 Nw. U. L. REV. 1038, 1050-51 (1979). The changing conceptions of childhood can be seen in the spread of the common-school movement, which sought to help youngsters develop their capabilities and unlock the potentials of mind and character. See 1 CHILDREN AND YOUTH IN AMERICA: A DOCUMIENTARY HISTORY 435 (Robert H. Bremner et al. eds., 1970) [hereinafter CHIIIDREN AND YouTH]. Hints of this changing conception of childhood appeared among the upper classes as early as 1750 . See REINIER, supra, at 25 , cmt. fig.l.

29. See Daniel T. Rodgers, Socializing Middle-Class Children: Institutions, Fables, and Work Values in Nineteenth-Century America, in GROWING UP IN AMERICA: CHIIDREN IN HISTORICAL PERSPECTIVE 119 (N. Ray Hiner \& Joseph M. Hawes eds., 1985).

30. See, e.g., The Manufacturing Interest, NiLES' WKLY. REG., Jan. 27, 1816, at 1 (advocating child labor in factories as a national necessity), reprinted in CHILDRE AND YOUTH, supra note 28, at 180; American Soc'y for the Encouragement of Domestic Manufactures, 
the 1830s, many Americans began to question the appropriateness of child labor. ${ }^{31}$ Fourteen states passed some sort of child labor restrictions between the late $1830 \mathrm{~s}$ and the $1850 \mathrm{~s},{ }^{32}$ although most of these laws were underenforced. ${ }^{33}$ The combined force of the cultural changes in views of children and legal restrictions on child labor was considerable. Between the $1820 \mathrm{~s}$ and the $1840 \mathrm{~s}$, most middle-class families withdrew their children from the labor force and kept them in schools, even though most children from working-class families still needed to work to supplement their families' income. ${ }^{34}$ These trends intensified through the end of the century, such that one historian speaks of a "sacralization" of children's lives from the nineteenth to the twentieth centuries. ${ }^{35}$

\section{Transformations in Child Custody Law}

The earliest American custody decisions were made according to the traditional English rule of paternal preference. ${ }^{36}$ Mothers almost never won custody of their children in divorce cases from the colonial era to the early nineteenth century. ${ }^{37}$ Beginning in the first third of the nineteenth century, however, the strict paternal preference rule began to erode. American

Address to the People of the United States (1817) (calling factories "seats of health and cheerfulness" for children), reprinted in CHIIDREN AND YOUTH, supra note 28, at 182.

31. See BoSTON EVENING TRANSCRIPT, Mar. 24, 1832 (reporting criticism of child labor by the New England Association of Farmers, Mechanics, and other Working-men), reprinted in CHIIDREN AND YOUTH, supra note 28, at 614; NEW YORK ASSEMBLY, REPORT OF THE COMMITTEE ON TRADE AND MANUFACTURES, ON THE MEMORIAL OF SUNDRY INHABITANTS IN THE COUNTIES OF ONEIDA AND OSTEGO, in 3 DOCUMENTS 1835, at 1-5 (1835) (noting that children in factories are "necessarily brought up in comparative ignorance, and are unfitted to become valuable citizens"), reprinted in CHILDREN AND YOUTH, supra note 28, at 617-18.

32. See CHILDREN AND YOUTH, supra note 28, at 627 fig.1, 628 fig.2.

33. See, e.g., MASSACHUSETTS HOUSE, REPORT OF THE SPECIAL COMMISSION ON THE Hours of LABOR AND THE CONDITION AND PROSPECTS OF THE INDUSTRIAL Classes, in DOCUMENTS 1866 at 3-11 (1866) (detailing violations of a Massachusetts child labor statute), reprinted in CHILDREN AND YOUTH, supra note 28, at 628-30.

34. See REINIER, supra note 28 , at 138.

35. See Viviana A. Zelizer, Pricing the Priceless Child: The Changing Social VALUE OF CHILDREN (1985). Although the new conception of children affected the middle and upper classes particularly strongly, see, e.g., MASON, supra note 27, at 52-53 (noting the prevalence of new conceptions of childhood among the urban middle class), the working classes were affected as well, see DEGLER, supra note 20, at 69-71. Still, child labor continued to be an important source of income for many working-class families throughout the 19th century. See StEPHANIE COONTZ, THE SOCIAL ORIGINS OF PRIVATE lifE: A History OF AMERICAN FAMIIIES 1600-1900, at 295 (1988); STEVEN MINTZ \& SUSAN KellogG, DOMESTIC REVOLUTIONS: A SOCIAL HISTORY OF AMERICAN FAMILY LIFE 90-91 (1988); ZELIZER, supra, at 58-61.

36. See James Schouler, A Treatise on the law of the DOMESTIC RELATIONS 333 (1870); Zainaldin, supra note 28, at 1053 n.48.

37. Children were not even mentioned in the 50 legislative divorces in Maryland between 1790 and 1815 , and were only mentioned in 13 of 89 divorces (15\%) between 1816 and 1825 . See CHUSED, supra note 17, at tbl.4. The same pattern prevailed in Connecticut and Massachusetts, where children were mentioned in almost no 18th-century divorces. See MASON, supra note 27, at 16. 
society in general became preoccupied with the "cult of motherhood," 38 and this cultural construct influenced judges making custody decisions as they became increasingly likely to award custody of the newly valued children to the mother. ${ }^{39}$ By the $1850 \mathrm{~s}$, the trend toward maternal preference was well-established, ${ }^{40}$ and by the end of the century, the custody of children after a divorce was almost always awarded to the mother. ${ }^{41}$

\section{B. The Rise of Family Desertion in Nineteenth-Century America}

The developments outlined in Section I.A primarily affected those members of nineteenth-century society who had the resources to take their marital problems to the courts. But for many wage-earning men, family desertion served as a cheap, nonlegal divorce. The strict colonial settlement laws ${ }^{42}$ and harsh punishments meted out to family deserters ${ }^{43}$ had kept desertion rates low in the colonies. ${ }^{44}$ In the nineteenth century, however, several social and economic transformations made it easier for men to leave their families. The breakdown of the settlement laws resulting from urbanization and immigration prevented towns from keeping out deserting husbands. ${ }^{45}$ As population growth overwhelmed the colonial poor-relief system, ${ }^{46}$ towns could not keep up with individual cases of desertion. The

38. This term describes the new emphasis that American society put on the role of the mother in raising children. See MASON, supra note 27, at 51.

39. See GROSSBERG, supra note 19, at 238-39, 281-83; MASON, supra note 27, at 49-83; RILEY, supra note 17, at 52; Zainaldin, supra note 28, at 1047-52. Mothers were especially valued under the "tender years" doctrine, in which custody of young or ill children was presumptively awarded to the mother, who was thought to have an innate ability to nurture and care for young children. See MASON, supra note 27, at 51; Zainaldin, supra note 28, at 1052-59.

40. See GROSSBERG, supra note 19, at 242, 248; Zainaldin, supra note 28, at 1052-59.

41. See GrosSBERG, supra note 19, at 253, 281-82. At the same time, courts retained considerable discretion over custody determinations. See id. at 281-85.

42. Most colonies enacted settlement laws soon after they were founded, restricting settlement in a town to persons who shared the town's religious beliefs and who could contribute to the town's economy. See, e.g., MARGARET CREECH, THREE CENTURIES OF POOR LAW ADMINISTRATION: A STUDY OF LEGISLATION IN RHODE ISLAND 43 (1936) (describing the settlement laws in Rhode Island); DAVID M. SCHNEIDER, THE HISTORY OF PUBLIC WELFARE IN NEW YORK STATE 1609-1866, at 49-50 (1938) (describing how New York settlement laws kept out those of questionable character or economic standing).

43. See, e.g., DEMOS, supra note 27 , at 92 (noting the colonial practice of banishment as punishment for desertion); EDMUND S. MORGAN, THE PURITAN FAMILY: RELIGION AND DOMESTIC RELATIONS IN SEVENTEENTH-CENTURY NEW ENGLAND 38 (2d ed. 1966) (describing a deserter who was fined and whipped); ROGER THOMPSON, SEX IN MIDDLESEX: POPULAR MORES IN A MASSACHUSETTS COUNTY, 1649-1699, at 123-24 (1986) (describing the court order to a deserting husband to maintain his family).

44. The town records of Middlesex, Massachusetts, list only two cases of wife desertion between 1649 and 1699. See THOMPSON, supra note 43, at 123.

45. See Raymond A. Mohl, Three Centuries of American Public Welfare: 1600-1932, CURRENT HIST., July 1973, at 8.

46. See infra note 52 and accompanying text. 
growth of large cities gave men who wanted to leave their families many places where they could go with relative anonymity. ${ }^{47}$ At the same time, the expansion of the shipping and manufacturing industries made it easier for men to take their labor power from one place to another. ${ }^{48}$ By early in the nineteenth century, wife desertion was starting to emerge as a major social problem. $^{49}$

\section{The Breakdown of the Early American Poor-Relief System}

The same social changes that had enabled more men to leave their wives during the nineteenth century also eroded the personal, individualized colonial poor-relief system. The colonists were usually able to take care of paupers individually, often by taking them into private homes ${ }^{50}$ or by giving them food or firewood. ${ }^{51}$ Population increases in the early nineteenth century made it impossible for this colonial system to provide for all of the needs of a town's poor. ${ }^{52} \mathrm{~A}$ shift in the American economy's primary orientation from agriculture to industry during the nineteenth century

47. See LINDA GORdON, PITIEd But Not ENTITLED: SINGLE MOTHERS AND THE HistORY OF WELFARE 1890-1935, at 26 (1994). For a discussion of the growth of cities in the 19th century, see generally PAUL BOYER, URBAN MASSES AND MORAL ORDER IN AMERICA, 1820-1920 (1978).

48. See Michael B. Katz, In the Shadow of the Poorhouse: A Social History of WELFARE IN AMERICA 5-6 (1986).

49. Exact dates and statistics about the rise of desertion in the early 19th century are almost nonexistent. One reason for this lacuna is that sociological data collection about poverty only began with the professionalization of public and private charity work, which did not occur until the $1870 \mathrm{~s}$ and $1880 \mathrm{~s}$. See generally ROY LUBOVE, THE PROFESSIONAL ALTRUIST: THE EMERGENCE OF SOCIAL WORK AS A CAREER, 1880-1930 (1965) (describing the professionalization of social work in the late 19th century). Even as late as 1916, one sociologist complained that the data on desertion was "fragmentary." EARLE EDWARD EUBANK, A STUDY OF FAMILY DESERTION 22 (1916). Social scientists in the early 20th century blamed 19th-century social changes such as industrialization and urbanization for the rise in desertion, arguingthough not providing exact data-that desertion increased concomitantly with these social transformations. See LILIAN BRANDT, FIVE HUNDRED AND SEVENTY-FOUR DESERTERS AND THEIR FAMILIES: A DESCRIPTIVE STUDY OF THEIR CHARACTERISTICS AND CIRCUMSTANCES 7 (1905) (providing a historical analysis of the rise of family desertion as a social problem); EUBANK, supra, at 9-14 (same); see also CHRISTINE STANSELl, CITY OF WOMEN: SEX AND CLASS IN NEW YORK, 1789-1860, at 12 (1986) (stating that desertion in New York may have increased during the 19th century because of the difficulties encountered by men trying to support their families).

50. See Walter I. Trattner, From POOR LAW to WELfare State: A History of SOCIAL WELFARE IN AMERICA 19 (3d ed. 1984).

51. See, e.g., Marcus Wilson Jernegan, The Development of Poor Relief in Colonial Virginia, in COMPASSION AND RESPONSIBILITY: READINGS IN THE HISTORY OF SOCIAL WELFARE POLICY IN THE UNITED STATES 36, 45 (Frank R. Breul \& Steven J. Diner eds., 1980) [hereinafter COMPASSION AND RESPONSIBLITY]; David M. Schneider, The Patchwork of Relief in Provincial New York, 1664-1775, in COMPASSION AND RESPONSIBILITY, supra, at 64, 66.

52. See TRATTNER, supra note 50, at 47; Charles R. Lee, Public Poor Relief and the Massachusetts Community, 1620-1715, 55 NEw ENG. Q. 564, 584 (1982); Thomas A. McMullin, Overseeing the Poor: Industrialization and Public Relief in New Bedford, I865-1900, 65 SoC. SERV. REV. 548, 559 (1991). 
created new classes of mobile laborers highly vulnerable to cyclical depressions, which threatened to overwhelm the colonial poor-relief system..$^{53}$ During the 1820 s, many towns constructed almshouses and other institutions in order to contain the growing numbers of poor people who lived in the community. ${ }^{54}$ The colonial relief system was being challenged and transformed at the same time that the twin revolutions in divorce and child custody were combining with the rise in desertion to create a new class of the economically vulnerable: single mothers with dependent children whose husbands were still alive.

\section{THE AMERICAN INVENTION OF A COMMON-LAW CHILD SUPPORT DUTY}

American courts in the nineteenth century addressed the problem of dependency among single mothers and their children by creating a legally enforceable child support duty. A legal child support obligation was unknown to English law, a fact that was repeatedly noted by courts and commentators skeptical of the new duty. But for the courts that supported the new doctrine (which was the majority view by the end of the century), ${ }^{55}$ the danger of dependency among single mothers-seen both as poverty and as dependency on the state ${ }^{56}$ - was enough to justify their departure from precedent. Courts early in the nineteenth century referred to concerns about dependency in the first American child support decisions. From midcentury to 1900, American courts consolidated the child support obligation, reasoning in a discourse of fault and punishment as they addressed dependency among single mothers.

\section{A. The Child Support Duty at English Law}

The American courts that dealt with cases of marital breakdown in the early nineteenth century had inherited a common-law tradition that did not provide for a child support action. Mainstream English law in the eighteenth and early nineteenth centuries had held that a father had only a nonenforceable moral duty to support his children. ${ }^{57}$ According to Blackstone, the duty of parents to provide for their children was a "principle of natural law." "N8 "Natural" law meant no more than that: There

53. See KATZ, supra note 48 , at 5-6; McMullin, supra note 52 , at 559 .

54. See KATZ, supra note 48 , at $10-11$.

55. See infra note 107.

56. See supra note 6.

57. See, e.g., Mortimore v. Wright, 151 Eng. Rep. 502 (Ex. of Pleas 1840); Bainbridge v. Pickering, 96 Eng. Rep. 776 (C.P. 1779); Urmston v. Newcomen, 111 Eng. Rep. 1022 (K.B. 1836).

58. 1 WILLIAM BLACKSTONE, COMMENTARIES *435. 
was no common-law action for the recovery of support furnished to a minor child at English law. ${ }^{59}$ There were some hints by the middle of the nineteenth century that English courts would imply a promise of reimbursement if a father refused to support a child, ${ }^{60}$ but these cases were clearly in the minority. Even the most generous reading of English precedent left American courts confused as to whether a father who deserted his family could be compelled to pay child support in a legal action. ${ }^{61}$ Most American courts read the English precedents as forbidding a third party from recovering child support costs unless a father had authorized such support by contract. ${ }^{2}$

England did have a statutory provision for the recovery of child support in limited circumstances. The Elizabethan Poor Law of 1601 authorized local parishes to recover the money they spent in aiding single mothers and children from a nonsupporting father. But this statute was triggered only when the family involved was absolutely destitute; it therefore provided no assistance to single mothers left economically vulnerable after a divorce or separation. Also, the Elizabethan Poor Law only allowed towns to recoup their relief costs. It allowed no recovery for third parties or for single mothers who needed to be reimbursed for child support expenses.

\section{B. Dependency and Punishment in Early American Child Support Law}

Despite the absence of a child support duty at English law, American courts early in the nineteenth century began to assert that a father had a legal duty to support his children. American judges in the nineteenth century knew quite well that they were inventing a duty that had not existed at English law. ${ }^{63}$ In Eitel v. Walter, ${ }^{64}$ for example, the New York

59. There was, however, a statutory action for recovery of child support costs by local parishes under the Elizabethan Poor Law of 1601. See infra notes 128-130 and accompanying text.

60. See, e.g., Rawlyns v. Vandyke, 170 Eng. Rep. 605 (C.P. 1800).

61. See, e.g., Dennis v. Clark, 56 Mass. (2 Cush.) 347, 353 (1848) (stating that the proposition that a father was bound at common law to maintain his children is "doubtful"); Raymond v. Loyl, 10 Barb. 483, 487 (N.Y. App. Div. 1851) (stating that a father's liability for his children in cases of desertion is "questio vexata" (a vexed question)).

62. See, e.g., Finch v. Finch, 22 Conn. 411, 418-19 (1853); Kelley v. Davis, 49 N.H. 187, 188-89 (1870); French v. Benton, 44 N.H. 28, 30 (1862); Fitler v. Fitler, 2 Phila. Rep. 372, 373 (Pa. 1857); Gordon v. Potter, 17 Vt. 348, 352 (1845) ("An examination of the English cases ... will show, that the parent cannot be made liable for necessaries, furnished to his child, without his consent, either express, or implied."); Varney v. Young, 11 Vt. 258, 260 (1839); see also JOHN B. MNOR, 1 INSTITUTES OF COMMON AND STATUTE LAW 413 (1882) ("In England the common law courts, after some fluctuation, seem to have settled down upon the doctrine that a parent is not obliged ... to pay for necessaries furnished an infant child ....").

63. See 2 JOEL PRENTISS BISHOP, COMMENTARIES ON THE LAW OF MARRIAGE AND DIVORCE $\$ 528$ (5th ed. Boston, Little, Brown, \& Co. 1873) (stating that the child support duty in cases of nonsupport is "a popular opinion, which has found its way into the ranks of the legal profession"); Donna Schuele, Origins and Development of the Law of Parental Child Support, 27 
Surrogate's Court acknowledged that English courts did not allow recovery for supporting a child who had been deserted or neglected by its father, but said abruptly that "I think a more humane doctrine prevails here, and that the father is held liable for necessaries, or, in other words, the law will imply a contract on his part, if he refuses or neglects to perform his natural duty to his offspring." ${ }^{65}$ Those who questioned the new doctrine were astounded at the readiness of most American courts to promote it. ${ }^{66}$ Even James Schouler, the author of a renowned treatise on domestic relations, who accepted the new child support doctrine, admitted that it was "to be justified rather by public policy than the well-understood liabilities of the father, as defined by Blackstone." 67

\section{Dependency Among Single Mothers and Children: The Earliest American Child Support Cases}

What was the "public policy" that justified the invention of a child support duty in nineteenth-century America? Some insights are provided by the two earliest American child support cases: Stanton v. Willson, ${ }^{68}$ decided by the Connecticut Supreme Court in 1808, and Van Valkinburgh $v$. Watson ${ }^{69}$ decided by the New York Supreme Court of Judicature in 1816. A desire to guard against dependency-in the dual sense of wanting to prevent poverty and wanting to prevent unnecessary drains on the public treasury-undergirded both of these opinions.

In Stanton, the Connecticut Supreme Court allowed Eunice Stanton to recover from her ex-husband on behalf of her deceased second husband, Joshua, for the support that Joshua had provided to Eunice's children from her first marriage. Two of Eunice's children had been awarded to her by a custody decree, and the third had fled from her ex-husband because of fears

J. FAM. L. 807, 815 (1989) (noting the trend toward announcing a child support duty "even when this required courts to employ a sleight of hand or resort to judicial fiat in order to arrive at such an outcome" (footnote omitted)). Even late in the 19th century, American courts were defensive about imposing an obligation that was so clearly absent from English law. See, e.g., Gilley v. Gilley, 9 A. 623, 624 (Me. 1887) (acknowledging opposing legal authority but holding that a legal child support duty is "the more consistent and humane doctrine").

64. 2 Bradf. 287 (N.Y. Sur. Ct. 1853).

65. Id. at 289. After stating the rule, the court did, however, deny the child support claim.

66. See W.R. Vance, The Parent's Liability for Necessaries Furnished His Minor Child, 6 VA. L. REG. 585, 590 (1901) (criticizing American case law supporting the child support duty because it is "rendered painfully uncertain by the rank growth of dicta, which seem to spring up in unusual luxuriance from the rich soil of sentiment and humanitarianism which surrounds such questions in a peculiar degree"); Note, Brow v. Brightman, 18 CENT. L.J. 469, 469 (1884) (observing a "noticeable lack of authority" supporting the proposition that a father has a legal duty to maintain his children).

67. SCHOULER, supra note 36 , at 328.

68. 3 Day 37 (Conn. 1808).

69. 13 Johns. 480 (N.Y. 1816). 
of personal violence. ${ }^{70}$ In a discursive opinion that bothered little with citation, the court authorized recovery for the support of the two children covered by the custody decree on the grounds of the unsupported statement that " $[p]$ arents are bound by law to maintain, protect, and educate their legitimate children, during their infancy, or nonage." ${ }^{71}$ The court allowed recovery for support of the third child because "[t]he infant cast on the world must seek protection and safety where it can be found; and where, with more propriety can it apply, than to the next friend, nearest relative, and such as are most interested in its safety and happiness?" 72

In Van Valkinburgh, which quickly became the leading case for the proposition that a father was legally responsible for the support of his children, ${ }^{73}$ the New York court denied a claim by a merchant to recover the price of a coat sold to a son on his father's credit. In sweeping dicta, the court wrote:

A parent is under a natural obligation to furnish necessaries for his infant children; and if the parent neglect that duty, any other person who supplies such necessaries is deemed to have conferred a benefit on the delinquent parent, for which the law raises an implied promise to pay on the part of the parent. ${ }^{74}$

In this case, they ruled, the father did not neglect his duty to provide necessaries for his son and hence was not liable to the store owner for the price of the coat. ${ }^{75}$

Both Stanton and Van Valkinburgh are notable for their casual assertion of a legally enforceable child support duty in the face of English precedent. But the opinions are also noteworthy for the grounds on which they situate the new child support obligation. Both courts enunciated a child support rule with an eye toward future factual situations in which the children would be in more precarious economic circumstances than they were in the cases at bar. The Connecticut Supreme Court in Stanton worried about the "infant cast upon the world," and created a rule that would protect that child when a case with more stringent economic circumstances presented itself. In Van Valkinburgh, the court's dicta speculated on a situation in which the father did not provide necessaries to his minor child-in other words, a case in which the minor child was going to become a pauper. The courts in both of these cases constructed a child support duty that would

70. See Stanton, 3 Day at 38-39.

71. Id. at 55 .

72. Id. at $57-58$.

73. Later cases citing to Van Valkinburgh as authoritative include Tomkins v. Tomkins, 11 N.J. Eq. 512, 517 (Ch. 1858); and Eitel v. Walter, 2 Bradf. 287, 289 (N.Y. Sur. Ct. 1853).

74. Van Valkinburgh, 13 Johns. at 480.

75. See id. 
later be able to serve as a private remedy for dependency among single mothers who otherwise would have to apply to towns for aid.

Even after Stanton and Van Valkinburgh, American courts felt so uncertain about the legal foundations of the new child support duty that they occasionally resorted to lengthy descriptions of the penury of the mothers and children involved in order to justify the courts' insistence on a legal child support duty. The New Jersey Court of Chancery resorted to this tactic in an 1858 decision, Tomkins v. Tomkins: ${ }^{76}$

If a case can be suggested where the moral obligation of a father to provide for his offspring can be enforced as a legal one, it would be difficult to find one more apposite than this. The complainant left his child, about three or four years of age, with its destitute and heart-broken mother. He abandoned them both to the charities of the world. The mother found shelter in the alms-house. The daughter was forced upon its grandmother, a woman then advanced in life, and of moderate means for her own support. There is no evidence that, for the fifteen years the child was under the care of its grandmother, the father ever made any inquiry as to its whereabouts or welfare. Now, in view of all these facts, if there was any doubt as to the legal obligation of the father to provide for his child, and of his legal liability to such as should supply that child with the necessaries of life, the moral obligation is so strong that a court of equity would feel but little inclined to grant relief, on any such ground as that the moral obligation had been converted into a legal one. ${ }^{77}$

There is a self-conscious act of legal creativity at work in this opinion: " $[\mathrm{f} f$ there was any doubt as to the legal obligation" (which of course there was, at the time), the court would still grant relief "on any such ground as that the moral obligation had been converted into a legal one." The court refused to allow the defendant to evade his obligation to reimburse the costs of caring for his impoverished child, and so it upheld a child support duty even though none had existed at common law.

The imminent dependency referred to by the courts in Stanton, Van Valkinburgh, and Tomkins recurred in almost every child support case decided by American courts during the nineteenth century because newly divorced mothers in nineteenth-century America almost always fell into poverty. ${ }^{78}$ Campbell v. Campbell ${ }^{79}$ decided by the Wisconsin Supreme

76. 11 N.J. Eq. 512 (Ch. 1858).

77. Id. at 517-18.

78. This is the background of Bishop's suggestion that paternal preference in child custody cases often served the best interests of the child by placing the child with the husband, who was after a divorce almost always the only parent who could adequately provide for the child. See BISHOP, supra note 63, § 542; see also, e.g., Ostheimer v. Ostheimer, 101 N.W. 275, 275 (Iowa 
Court in 1875, provides one example: Mrs. Campbell obtained a divorce from Mr. Campbell, won the custody of their only child, and secured a child support order of one dollar per week and alimony of one hundred dollars per year from Mr. Campbell. ${ }^{80}$ By all accounts, the Campbells were members of the middle or upper class. Chief Justice Ryan observed that they "appear to be quite intelligent, and ... quite respectable." ${ }^{81}$ After the divorce, however, their fortunes diverged. Mr. Campbell "seems to have thriven, since he escaped from the expense of maintaining the respondent and their child.... We take his present estate [of about $\$ 13,500$ ] to be in part owing to the economy of the divorce to him." ${ }^{82}$ Mrs. Campbell's story was quite different. Soon after the divorce, their child fell sick, "perhaps dangerously so. Mother and child seemed not unlikely to come to want." ${ }^{83}$ Mrs. Campbell moved to Chicago, where she lived with her sister until commencing the child support action. ${ }^{84}$ The fortunes of the Campbells were typical of many divorced couples who were relatively well-off at the time of the divorce: The man almost always profited; the woman almost always came close to destitution. ${ }^{85}$

One reason for the divergent fortunes of men and women after a divorce was that the transformations in the American conception of children from wage earners to dependents who needed constant nurturing ${ }^{86}$ and the trend toward maternal preference in custody decisions ${ }^{87}$ combined to require divorced women to bear the burden of raising children who did not work. ${ }^{88}$ Another reason for the poverty of newly divorced mothers was the market that they faced for their own labor: Most employed women in the nineteenth century earned less than half of what employed men did, making

1904) (noting that after a divorce the husband had "substantially increased his holdings, and [was] in much better condition to assist in the support of his children than he [had been] at the date of the divorce" while the wife was "in straitened circumstances, and needs assistance to adequately supply the wants of the children"); Finley v. Finley, 2 S.W. 554, 554-55 (Ky. 1887) (stating that a divorce had left the mother and child "both penniless, and in a dependent condition, requiring them to look to the charity of friends and relations for maintenance and support" but the father was "engaged in business, and in a moral, if not in a pecuniary, point of view, is fitted to take charge of his infant daughter"); Nugent v. Powell, 33 P. 23, 24 (Wyo. 1893) (describing a deserting husband as having left his family "without money or means of support, and in circumstances of extreme destitution" while "he was earning reasonable wages").

79. 37 Wis. 206 (1875).

80. See id. at 209.

81. Id. at 223.

82. Id. at 223-24.

83. Id. at 222.

84. See id. at 222.

85. See supra note 78.

86. See supra Subsection I.A.2.

87. See supra Subsection I.A.3.

88. The claims from early child support cases provide detailed examples of exactly how expensive raising a child was in the 19th century. See, e.g., Pretzinger v. Pretzinger, 15 N.E. 471, 472 (Ohio 1887) (reporting that the plaintiff claimed expenses of $\$ 258$ per year for raising a child). 
it almost impossible for a single mother to support a family without supplementary income. ${ }^{89}$

\section{Dependency and Punishment: American Child Support from 1850 to 1900}

During the latter half of the nineteenth century, American courts became more confident in asserting a legal child support duty when they were presented with poor single mothers and their children. American courts faced this situation in two related factual contexts. In the first, a local benevolent individual had provided food and clothing to young children, and he later sued the children's father for reimbursement. In the second, the divorced mother had managed to support the children, and she wanted to recover her costs from her ex-husband. In both cases, courts readily upheld claims against the father, referring constantly to the pressing dependency of the mother and children involved, and finding fault with the father who had caused the marital breakdown and subsequent dependency.

Once the child support duty had been legally established, many of the early child support claims were brought by individuals who had provided food, board, or clothing to impoverished single mothers and their children and wanted to recover their outlays from the present or former husband ${ }^{90}$ In Reynolds v. Sweetser, ${ }^{91}$ for example, the Supreme Judicial Court of Massachusetts authorized John Reynolds's bid for recovery from Stephen Sweetser when Sweetser's wife and child had left him after he had physically abused them. The court reasoned that Reynolds could recover because Sweetser had "made no suitable provision, either at his own home or elsewhere, for the mother and child" and had "utterly failed ... to relieve [his child] from the absolute destitution to which by his neglect and misconduct it had been exposed." 92 The keys to this decision are "absolute destitution" and the father's "neglect and misconduct": The wife and child were destitute because of an abusive husband and father; the court was quick to authorize recovery for the generous individual who came to their aid. ${ }^{93}$

89. See Reva B. Siegel, Home as Work: The First Woman's Rights Claims Concerning Wives' Household Labor, 1850-1880, 103 YALE L.J. 1073, 1128 n.186 (1994); see also McCloskey v. McCloskey, 67 S.W. 669, 671 (Mo. Ct. App. 1902) (noting that a father has no right to shift his duty to protect his children from want "onto the mother, often and almost always much less able to cope with the world and earn money than he is").

90. See, e.g., Cromwell v. Benjamin, 41 Barb. 558 (N.Y. App. Div. 1863); Gill v. Read, 5 R.I. 343 (1858).

91. 81 Mass. (15 Gray) 78 (1860).

92. Id. at 81 .

93. Sometimes, courts even allowed this common-law action of recovery to towns that aided poor mothers and their children. See, e.g., Town of Rumney v. Keyes, 7 N.H. 571 (1835). 
As the doctrine developed after the 1850s, courts applied a two-part legal test in these types of situations. First, courts asked whether the items provided by the plaintiff were "necessaries." Only those items required for bare subsistence, such as food and clothing, qualified. Second, courts asked whether the father had failed to provide the children with those items. ${ }^{94}$ This formulation of the child support obligation in the context of third-party claims had the result of requiring both dependency (the items provided were necessaries) and fault (the father had failed to provide them) before a plaintiff could recover child support costs.

Before long, American courts applied the child support doctrine to allow newly divorced mothers to recover directly from their husbands for their outlays in supporting their children. As was the case for third-party plaintiffs, divorced mothers had to prove that their ex-husband was at fault in failing to support the children. However, courts usually placed an additional burden on single mother plaintiffs that they did not place on third-party plaintiffs. Single mothers who wanted to recover for child support had to prove not only that their husband had failed to provide for the children, but also that the husband was at fault for causing the divorce. ${ }^{95}$ If the wife was at fault, she could not recover child support. ${ }^{96}$ As David Stewart explained in his 1884 treatise on marriage and divorce:

94. See 2 JAMES KENT, COMMENTARIES ON AMERICAN LAW 162 (photo. reprint 1971) (1827) ("If the father suffers the children to remain abroad with their mother, or if he forces them from home by severe usage, he is liable for their necessaries."); Smith v. Church, 12 N.Y. Sup. Ct. 109 (App. Div. 1875). The presence of this test did not mean, however, that recovery was absolutely precluded if the items provided were not necessaries-only that in such a case, the plaintiff would have to show an implied or express contract to justify recovery. See Fowlkes $v$. Baker, 29 Tex. 135, 140-41 (1867). Hence, the doctrine prevented dependency while sanctioning only a limited invasion on the ability of parents to support children in their own homes where the children were under the parents' control. See Leslie J. Harris et al., Making and Breaking Connections Between Parents' Duty To Support and Right To Control Their Children, 69 OR. L. REV. 689, 703-04 (1990).

95. As Joel Bishop stated in his 1873 domestic relations treatise:

When the court pronounces for a divorce, pursuant to the prayer of the wife, and gives her the custody of the children; then, in respect to their support, the rule would apply to the husband, that no man shall profit by his own wrong, and, to the wife, the corresponding rule, recognized by good sense, if not so formally received as the other among the maxims of the legal family, that no one shall suffer for doing right; in pursuance of which, the husband should be charged with the full burden of maintaining the children committed to the wife's care.

BISHOP, supra note 63, at $\$ 555$; see Plaster v. Plaster, 47 Ill. 290, 292 (1868); Gibson v. Gibson, 51 P. 1041, 1042 (Wash. 1898); THEOPHILUS PARSONS, 1 THE LAW OF CONTRACTS 295 (4th ed. Boston, Little, Brown \& Co. 1860) ("[W]here [the child] has been deserted by the father, or driven away from him, either by command or by cruel treatment, there the infant carries with him the credit and authority of the father for necessaries."); Schuele, supra note 63, at 824.

96. See, e.g., Fulton v. Fulton, 39 N.E. 729 (Ohio 1895); see also L.W.B., Annotation, Liability of Father for Support of Children Awarded to Mother by Decree of Divorce Not Providing for Maintenance, 15 A.L.R. 569, 572 (1921) ("Since the rule that a father is liable for the support of his children though he has, by a decree of divorce, been deprived of their society and services, is based on the fact that his fault produced the condition, the rule has been held to be inapplicable where the divorce is granted for the fault of the wife."). But see Hoit v. Holt, 42 Ark. 
[A] wife who is without means and without fault may pledge her husband's credit for necessaries for children who are in her custody through his fault or his consent, but not if she is in fault, or holds the children without fault on his part and against his wishes. ${ }^{97}$

In claims for child support after divorces based on the husbands' fault, ${ }^{98}$ courts usually ordered divorced men to support their ex-wives and children. If women could find their deserting husbands, courts readily ordered the husbands to pay child support. ${ }^{99}$ Similarly, courts often awarded child support to women who had been divorced from their husbands on the grounds of their husbands' cruelty. ${ }^{100}$

Even though women often prevailed in these suits, their victories rarely resulted in economic stability for their families. If child support was awarded, the father was "only bound for a bare maintenance." 101 A deserted wife was held to a stringent budget by courts who said that her ability to recover depended on the "reasonableness and propriety of her expenditures." 102 The child support awards were so low-usually about five dollars per week-that they did not approach full reimbursement for the costs of maintaining a child. ${ }^{103}$ One mother, for instance, received only one dollar per week in child support immediately after the divorce. ${ }^{104}$ In an economy in which women earned less than half of men's wages, ${ }^{105}$ these

495 (1883) (allowing a wife to recover child support even though she was at fault in the divorce); Rankin v. Rankin, 83 Mo. App. 335 (Ct. App. 1900) (same).

97. DAVID STEWART, THE LAW OF MARRIAGE AND DIVORCE $\S 405$ (S.F., Sumner Whitney $\&$ Co. 1384) (footnotes omitted).

98. See supra notes 23-24.

99. See, e.g., Plaster, 47 Ill. at 292; Gilley v. Gilley, 9 A. 623, 624-25 (Me. 1887); see also McCloskey v. McCloskey, 67 S.W. 669, 672 (Mo. Ct. App. 1902) (noting that a deserting husband had left his children "to get along as best they could; that is, to be taken care of by their mother, or starve").

100. See, e.g., Abele v. Abele, 50 A. 686 (N.J. Ch. 1901); Parker v. Parker, 42 A. 160 (N.J. Ch. 1899); Gibson, 51 P. at 1041.

101. Cowls v. Cowls, $8 \mathrm{Ill}$. ( 3 Gilm.) 435, 442 (1846) (awarding $\$ 60$ per year for five years for the support of two infant children). Ostensibly, child support awards were tied to the income of the father. See McGoon v. Irvin, 1 Pin. 526, 531 (Wis. 1845) ("The law will presume that a man of great means will have his children more tenderly nurtured and carefully educated than one of limited means, and raises a corresponding liability."). Some child support awards for the children of exceptionally wealthy couples were, indeed, generous. See, e.g., Ahrenfeldt v. Ahrenfeldt, 4 Sand. Ch. 493 (N.Y. Ch. 1847) (awarding $\$ 350$ per year to send a ten-year-old girl to boarding school, with a provision that the award will be increased if expenses necessitate it); Gibson, 51 P. at 1041 (noting that a father was "amply able" to pay $\$ 150$ per year in child support for an eleven-year-old girl). But even the children of wealthy fathers usually received minimal support. See, e.g., Cox v. Cox, 25 Ind. 303 (1865) (awarding $\$ 50$ per year for a child even though her father's net worth was at least $\$ 20,000$ ).

102. Holt v. Holt, 42 Ark. 495,500 (1883).

103. See, e.g., Bush v. Bush, 37 Ind. 164, 168 (1871) (upholding an award of $\$ 100$ per year per child after a divorce but admitting that such an award "will not pay for [the children's] clothing and education"); Buckminster v. Buckminster, 38 Vt. 248 (1865) (awarding $\$ 50$ twice per year for four children, one of whom was ill).

104. See Campbell v. Campbell, 37 Wis. 206, 209 (1875).

105. See supra note 89 and accompanying text. 
low levels of child support combined with the expense of maintaining a child kept single mothers just above the threshold of poverty.

Even though women were disadvantaged by having to prove their husbands' fault, and even though the child support awards were low, the child support obligation kept poor women and children off town poor-relief. Hence, courts would often state that a father who paid child support fulfilled his duty "to the public" to ensure that his children did not receive charity. ${ }^{106}$ By the end of the nineteenth century, a legally enforceable duty to support children was accepted in most American states, ${ }^{107}$ and philanthropic individuals and single mothers were able to recover from nonsupporting fathers, keeping many single mothers from having to ask their towns for relief.

\section{Child Support for Black Families in the Nineteenth Century}

The child support system that developed in American courts in the nineteenth century was open only to white families. Under slavery, almost no blacks in either the Northern states that permitted slavery or in the South were permitted to marry. ${ }^{108}$ Because black men under the slave system were not married heads of household with legal rights and duties, child support was a moot issue. Black fathers had no legal existence under slavery, and hence they were not liable for child support. ${ }^{109}$ Black children under slavery had no legal father, and hence they could not claim maintenance from their parents. ${ }^{110}$ Instead, the primary responsibility for the support of black children under slavery belonged to the white, male slaveholder, who often was described by proslavery advocates as the "head" of a "household" of black adults and children. ${ }^{111}$ Also, the idealization of white children that

106. Steele v. People, 88 Ill. App. 186, 187 (App. Ct. 1899). See also, e.g., Courtright v. Courtright, 40 Mich. 633, 635 (1879) (stating that a father had a duty to his children and "as against the public" to support his children after a divorce).

107. See Vance, supra note 66, at 593-94 (" [] $\mathrm{t}$ may be safely said that according to the American authorities a father is under a legal obligation to maintain his minor child irrespective of statute... That such a legal duty of support is recognized in the United States cannot well be called in question in view of the great mass of authority, both of reported decisions and legal treatises that so state the law."); Ernest Watts, Porter v. Powell-The Right to Parental Support, 39 AM. L. REG. 28, 55 (1891) ("The weight of the authorities would, however, seem to be in favor of holding the duty to be one enforceable at common law as a duty cast upon the father thereby...."); see also Schuele, supra note 63, at 815 n.34 (describing the shift to general acceptance of a child support duty).

108. See GROSSBERG, supra note 19, at 129 (noting the infrequency of slave marriages in the North); id. at 130 (describing prohibitions on slave marriages in the South); Margaret A. Burnham, An Impossible Marriage: Slave Law and Family Law, 5 LAW \& INEQ. J. 187, 207-11 (1987).

109. See Burnham, supra note 108 , at $208,211$.

110. See id. at 218.

111. See Jill Elaine Hasday, Federalism and the Family Reconstructed, 45 UCLA L. REV. 1297, 1325-26 (1998). 
occurred in the 1830s did not affect black children at all. White society throughout the nineteenth century continued to view black children primarily as income-generating assets, usually as property for white slaveowners. ${ }^{112}$

After the Civil War, legal prohibitions on marriage for blacks were lifted, and many black couples formalized the unofficial unions that had developed under slavery. ${ }^{113}$ Still, many black couples rejected formal marriages, choosing instead to maintain informal, unofficial marriages. At least half of all unions between blacks in North Carolina were of this nature, by one estimate. ${ }^{114}$

Even legally sanctioned marriages did not give black fathers either the right to direct the upbringing of their children or the duty to support them. Soon after the Civil War, most Southern states passed "apprenticeship" statutes as part of the Black Codes. These statutes allowed whites to indenture black children, regardless of whether the children lived with their families or whether their parents were working to support them. ${ }^{115}$ The statutes essentially reintroduced slavery for black children. As a result, black men in the period after the Civil War were only under legal child support obligations when their children could not be successfully indentured. ${ }^{116}$

112. See Burnham, supra note 108 , at 216; see also JAMES OLIVER HORTON, FREE PEOPLE OF COLOR: INSIDE THE AFRICAN AMERICAN COMMUNITY 99-100 (1993) (noting that slave children in the North were the property of the slaveowner, increasing the economic value of female slaves).

113. See GRosSBERG, supra note 19, at 133; Laura F. Edwards, "The Marriage Covenant Is at the Foundation of All Our Rights": The Politics of Slave Marriages in North Carolina After Emancipation, 14 LAW \& HIST. REV. 81, 101 (1996).

114. See Edwards, supra note 113, at 107. After the abolition of slavery in the North, demographic evidence suggests that the number of female-headed households in the black community rose steadily during the 19th century, similar to the demographic shift that occurred in the white community. See JAMES OLIVER HORTON \& LOIS E. HORTON, IN HOPE OF LIBERTY: CUlTURE, COMMUNITY, AND PROTEST AMONG NORTHERN FREe BlaCKs, 1700-1860, at 86 (1997). The primary cause of the rise in female-headed households for black families in the 19th century, however, was the high mortality rate among black males, in contrast to the divorce and desertion that led to the creation of female-headed households in the white community. See id. at 86-87.

115. See GROSSBERG, supra note 19, at 266; TERA HUNTER, TO "JOY MY FREEDOM": SOUTHERN BLACK WOMEN'S LIVES AND LABORS AFTER THE CIVIL WAR 35-36 (1997); Sara Rapport, The Freedmen's Bureau as a Legal Agent for Black Men and Women in Georgia: 18651868,73 GA. HIST. Q. 26, 35 (1989). The North Carolina statute, for instance, allowed whites to apprentice black children "when the parents with whom such children may live do not habitually employ their time in some honest, industrious occupation." Edwards, supra note 113, at 97 (citation omitted).

116. As one historian has concluded: "Marriage, considered in light of the apprenticeship laws, did not make African-American men household heads with the power to protect the interests of their dependents. It simply obligated them to support their dependents when it was inconvenient and unprofitable for white planters to do so." Edwards, supra note 113, at 98. Many whites supported marriage for blacks precisely because it would provide a fall-back system of legal obligations-including child support obligations-the breach of which could be legally 
These statutes did not last long. While the apprenticeship laws were in force, many freedpeople managed to keep their children from being indentured to former slaveholders. ${ }^{117}$ The freedpeople also deluged the Freedmen's Bureau with complaints about the laws, forcing the Bureau to press for the laws' abolition. ${ }^{118}$ By the late 1860 s and early 1870 s, the combined efforts of the freedpeople and the Freedmen's Bureau had overturned most apprenticeship statutes. ${ }^{119}$

Although the evidence is scarce, it appears that the main point of entry for black families into the nineteenth-century child support system was through the so-called bastardy or illegitimacy statutes. ${ }^{120}$ Most American states early in the nineteenth century enacted such laws, designed to compel a putative father to support his out-of-wedlock children. ${ }^{121}$ The American illegitimacy statutes were borrowed from similar English laws that were intended (like the support obligation for divorced fathers) to relieve towns from the burden of aiding poor children. ${ }^{122}$ Perhaps because of the unofficial nature of many black marriages in the late nineteenth century, prosecutions against black fathers for nonsupport occurred under the illegitimacy laws instead of through the common-law support obligation developed for divorced mothers.

Direct legal action against nonsupporting fathers was only one way in which single black mothers could obtain help in feeding and clothing their children. Many black adults, especially in Northern cities, boarded themselves out to other families to save on living costs. ${ }^{123}$ Many black families also readily took in children from other families for long periods of time. ${ }^{124}$ These networks of mutual self-help probably provided single black mothers with opportunities to support their children without relying on child support payments from absent fathers.

prosecuted. See id. at 94 . If a black couple was not legally married, it was even easier for their children to be apprenticed. See id. at 105.

117. See id. at 103-05.

118. See id. at 102-05; Hasday, supra note 111, at 1355-57.

119. See Edwards, supra note 113, at 119; Hasday, supra note 111, at 1355-57.

120. See GROSSBERG, supra note 19, at 226-27; Edwards, supra note 113, at 108.

121. See $2 \mathrm{KENT}$, supra note 94 , at 178 ("[R]egulations to coerce the putative father to maintain the child, and indemnify the town or parish, have been adopted in the several states."). See generally GROSSBERG, supra note 19, at 196-233 (describing the illegitimacy laws in 19thcentury America).

122. See 4 CHESTER G. VERNIER, AMERICAN FAMILY LAWS 207 (1936).

123. See JAMES Oliver HoRTON \& LOIS E. HORTON, BLACK BOSTONIANS: FAMILY LIFE AND COMMUNTTY STRUGGLE IN THE ANTEBELLUM NORTH 16 (1979).

124. See id. at 18-19; HUNTER, supra note 115 , at 37 . 


\section{THE TRANSFORMATION OF AMERICAN CHIID SUPPORT LAW AND THE CRIMINALIZATION OF NONSUPPORT: STATUTORY REMEDIES FOR POOR WOMEN}

Although there was no common-law action for child support in England, the Elizabethan Poor Law of 1601 allowed towns to sue fathers who did not support their children. Most American states enacted similar laws. ${ }^{125}$ When the colonial poor-relief system broke down in the nineteenth century, ${ }^{126}$ however, reformers started to look for ways other than the poor laws to force fathers to support their children. In the 1870s and 1880s, many states passed desertion and nonsupport statutes that criminalized refusal to support one's children. These statutes added the punitive power of the criminal law to the dependency focus of the civil child support obligation, punishing those fathers who caused single mothers and children to become dependent on state aid. The statutes also showcased the fiscally conservative aspect of child support in the nineteenth century: They were intended primarily as a way to save public resources, not as measures intended to enhance child welfare. ${ }^{127}$

\section{A. The Elizabethan Poor Law and its American Counterparts}

Statutory child support obligations to prevent the worst cases of absolute destitution were well-known in Anglo-American jurisprudence. The first such statute was the Elizabethan Poor Law of $1601 .{ }^{128}$ The Poor Law required parents to maintain both their minor and their adult children if the children were otherwise going to become paupers. ${ }^{129}$ This was mainly symbolic, however, as the penalty was only a fine of twenty shillings per month. Children of any age were expected to work so that they would not be poor, because, as Blackstone reasoned, "the policy of our laws, which

125. See TAPPINg ReEve, THE LAW OF BARON AND FEMME 414 (photo. reprint 1970) (1862); SCHOULER, supra note 36, at 320 ("The stat. 43 Eliz. may be considered as having been transported to the United States as part of our common law. Its provisions have also been reenacted in many of our states....").

126. See supra Section I.C.

127. By conceptualizing modern American welfare programs as having two broad goalsencouraging work among aid recipients and saving as much public money as possible-we can see that the criminal law in the 19th century served as a tool of the welfare state in both of these areas. Laws against vagrancy forced working-class adults into exploitative labor contracts. See Christopher L. Tomlins, Law and Power in the Employment Relationship, in LABOR LAW IN AMERICA: HISTORICAL AND CRITICAL ESSAYS 71 (Christopher L. Tomlins \& Andrew J. King eds., 1992). Meanwhile, laws against nonsupport saved the public from the expense of aiding deserted wives and children.

128. 43 Eliz. c. 2 (Eng. 1601).

129. See Jacobus tenBroek, California's Dual System of Family Law: Its Origin, Development, and Present Status (pt. 1), 16 STAN. L. REV. 257, 279-87 (1964) (detailing the child support provisions in the Poor Law). 
are ever watchful to promote industry, did not mean to compel a father to maintain his idle and lazy children in ease and indolence ...."130

When American courts began to confront the problems of marital breakdown and dependency among single mothers in the early nineteenth century, one of the first places to which they looked for help was the provisions of the state poor laws, lifted in many cases directly from the Elizabethan Poor Law statute. ${ }^{131}$ The American poor laws continued to be a vital way for towns, rather than generous individuals or single mothers, to recover child support from nonsupporting fathers. ${ }^{132}$

Sterling $v$. Commonwealth, ${ }^{133}$ decided by the Pennsylvania Supreme Court in 1858, shows how the poor-law remedy for nonsupport operated. On September 16, 1857, one of the Directors of the Poor and of the House of Employment of the County of Beaver demonstrated before two justices of the peace that William R. Sterling had deserted Matilda Sterling, his wife, and their child, "leaving her and it a charge on the county." 134 The justices of the peace issued a warrant authorizing the Directors of the Poor to seize Sterling's goods and chattels. The lower court sustained the warrant and proceedings against a complaint by William Sterling and decreed that he should pay the town $\$ 300$ per year for the support of his wife and seventy-five dollars per year for the support of their child..$^{135}$

As Sterling and similar cases show, the poor-law child support provision addressed only the most dire cases of dependency among single mothers and their children. As was the case in England, the American poor laws provided only the bare minimum in child support allowances. Chancellor Kent referred to the poor-law child support provisions as "feeble and scanty" and only "intended for the indemnity of the public against the maintenance of paupers." ${ }^{136}$ The breakdown of the early

130. 1 WILLIAM BLACKSTONE, COMMENTARIES *437.

131. See supra note 125.

132. See, e.g., City of New Bedford v. Chace, 71 Mass. 28, 30-31 (1855) (holding that towns could only aid married women and their children through the poor law process); Hanover v. Turner, 14 Mass. 227, 230-31 (1817) (allowing the town of Hanover to recover from Isaac Turner for aid rendered to his impoverished wife); see also tenBroek, supra note 94, at 291-306 (discussing poor law child support provisions in New York).

133. 2 Grant 161 (Pa. 1858).

134. Id. at 162 .

135. See id. at 165 . The poor law provisions were burdensome for working-class families, as they required the father to impoverish himself completely before a town would give any aid to his children. See, e.g., Garland v. Dover, 19 Me. 441, 446 (1841). Courts deciding cases under the poor laws feared that anything less would weaken work incentives among working-class families. As the New Hampshire Supreme Court said in 1827:

A man's wife and his infant children cannot become a charge upon a town as paupers until he is a pauper. Sound policy requires that it should be so. For if the rule of law given to the jury in this case were applicable to unemancipated children, every man in moderate circumstances might throw his young children upon the town for support until they became able to support themselves.

Hillsborough v. Deering, 4 N.H. 86, 96 (1827).

136. 2 KENT, supra note 94 , at 161 . 
American relief system outlined in Section I.C meant that the kinds of individualized, personal remedies provided by the poor laws were becoming increasingly impractical. In addition, the poor laws only allowed towns to sue fathers to recover their outlays in maintaining children. They made no provision for those parties who complained under the commonlaw support action: philanthropic individuals and the single mothers themselves. As such, they were almost exclusively measures designed to protect the public fisc, not to ensure the welfare of the children involved. ${ }^{137}$

\section{B. The Rise of Criminal Nonsupport Statutes}

In response to the weaknesses of the poor laws, a spate of new desertion and nonsupport laws were passed in the 1870s and 1880s. The new laws, like the poor laws, were only triggered by absolute destitution. But unlike the poor laws, they allowed for transfers of child support payments to poor single mothers themselves. An 1886 compilation of American statutes noted that eleven states had made it a penal offense for a father to abandon or refuse to support his minor children. ${ }^{138}$ By enacting these laws, American states made nonpayment of child support a serious crime, punishable by a criminal penalty.

This was exactly how the courts saw the new desertion and nonsupport laws when cases began to be brought under them late in the nineteenth century. Courts interpreted the laws as creating criminal sanctions for those who caused dependency. The aim of the laws was one typically associated with the welfare state-the prevention of dependency. But the form of the laws was based on a criminal justice model - the punishment of offenders against public peace.

137. See Chas. A. Bucknam, Parent and Child, 15 CENT. L.J. 23, 23 (1882) ("[T] he statutes are intended only for the indemnity of the public against paupers, and not for the reimbursement of an individual who may have relieved the sufferings and distress of needy persons...."); Vance, supra note 66, at 593 ("[The poor law] can be invoked only in aid of the public, and never for the benefit of the child.").

138. See Frederic J. STIMSON, AMERICAN STATUTE LAW 751 (Boston, Charles C. Soule 1886). More states passed desertion statutes around the turn of the century. In 1904, the University of Chicago social scientist and social reformer Charles Richmond Henderson noted a "tendency in the United States to compel men to support their families in case of neglect." ChARLes Richmond HENDERSON, MODERN METHODS OF ChaRITY: AN ACCOUNT OF THE Systems OF RELIEF, PUBlic AND PRIVATE, IN THE PRINCIPAL COUNTRIES HAVING MODERN METHODS 303 (1904). Between 1905 and 1911, 14 states passed legislation making desertion a misdemeanor, 11 states passed laws making it a felony, and 19 states passed laws related to technical aspects of desertion law, such as the evidence required to prove desertion. See WiLLIAM H. Baldwin, THE PRESENT Status OF Family DESERTION aNd NONSUPPORT Laws 1-2 (1911); see also SUSAN TIFFIN, IN WHOSE BEST INTEREST? CHILD WELFARE REFORM IN THE PROGRESSIVE ERA 147-61 (1982) (describing the passage of nonsupport laws in the early 20th century). 


\section{Dependency}

The narrow focus of the new criminal nonsupport laws on preventing dependency on the state can be seen in three ways: the role of private charitable agencies in lobbying for and enforcing the laws, the interpretations of the new laws in the courts, and the low levels of monetary support awarded under the laws. In the 1870 s and 1880 s, private charitable societies realized that deserted mothers and their children were a significant burden on the charities' relief coffers. ${ }^{139}$ These societies actively lobbied state legislatures to enact desertion and nonsupport laws. ${ }^{140}$ Private charitable societies acted as quasi-public agents, bringing complaints under the laws, collecting funds from deserting husbands, and disbursing them to deserted wives. In 1895, the Humane Society of Cincinnati investigated 937 cases of deserting or nonsupporting fathers, won arrests or support orders for 654 of them, and collected and paid out $\$ 13,947.94$ in child support. ${ }^{141}$ The United Workers of Norwich, Connecticut, arranged to collect the wages of convicted deserting husbands. The United Workers disbursed these sums to the families. They handled between 400 and 500 men in this way from 1890 to $1895 .{ }^{142}$

When the courts began to decide what constituted "nonsupport" under the new statutes, they usually said that the statutes applied only to cases in which the mother and children would become a charge on the public if the husband did not support them. In a prosecution under Indiana's desertion and nonsupport statute, the Indiana Supreme Court sustained a quashing of an indictment that charged that Isaac Rice deserted his wife without making provision for her comfortable support, noting that if the prosecution were allowed, "a worthless husband might be fined for deserting his wife, even though she possessed a fortune amply sufficient for her support." ${ }^{143}$ The New Jersey statute, which allowed those who did not support their wives and children to be adjudged disorderly persons and required to pay a weekly sum for the support of their families, was interpreted in a similar manner. In 1896, the Supreme Court of New Jersey overturned a conviction

139. See Foundlings and Deserted Children, in PROCEEDINGS OF THE EIGHTH ANNUAL CONFERENCE OF CHARITIES AND CORRECTION 282, 282-84 (1881) (statement of Susan I. Lesley, Phil. Soc'y for Organizing Charity).

140. See, e.g., MASSACHUSETTS SOC'Y FOR THE PREVENTION OF CRUELTY TO CHILDREN, SECOND ANNUAL REPORT 15-17 (1882); see also Martha May, The "Problem of Duty": Family Desertion in the Progressive Era, 62 SOC. SERV. REV. 40, 43-44 (1988) (describing charity workers' suggestions for legal reform during the late 19th century).

141. See E.P. Savage, Desertion by Parents, in PROCEEDINGS OF THE TWENTY-FOURTH NATIONAL CONFERENCE OF CHARITIES AND CORRECTIONS 317, 320 (1897).

142. See G.W. Swan, Remarks at the Twenty-Second National Conference of Charities and Corrections, in PROCEEDINGS OF THE TWENTY-SECOND NATIONAL CONFERENCE OF CHARITIES AND CORRECTIONS, 1895, at 519, 520 (1895).

143. State v. Rice, 5 N.E. 906,907 (Ind. 1886). 
under the statute on the grounds that there was no finding that the family of the defendant would become chargeable to the city. ${ }^{144}$

The low levels of child support awarded under the statutes also served to emphasize that the main goal of the statutes was to prevent dependency on the state. Like the civil child support awards, the statutory nonsupport provisions were intended to ensure only a "bare maintenance." 145 Most awards clustered between two and five dollars per week-hardly enough to support a mother with a young child adequately, but just enough to keep her from applying to the town for aid..$^{146}$

\section{Punishment}

The new nonsupport statutes displayed their criminal, punitive intentions in both their statutory language and the courts' interpretation of them. The early desertion and nonsupport statutes made the criminal nature of the offense clear. The New Jersey statute, enacted in 1884, punished nonsupporting fathers with imprisonment and hard labor "in the same manner as other prisoners committed to such jail or workhouse are put and kept at hard labor." 147 The typical criminal penalties imposed for nonsupport were fines, ${ }^{148}$ imprisonment, ${ }^{149}$ or both ${ }^{150}$ Some laws provided for the suspension of the sentence if the father could provide a bond for the future support of his wife and child. ${ }^{151}$ The legislatures that drafted nonsupport statutes were following the prevailing cultural paradigm for understanding child support: Professional charity workers during this period repeatedly used the language of punishment to describe how they dealt with deserting or nonsupporting husbands. ${ }^{152}$

144. See State v. Watson, 33 A. 943 (N.J. 1896); see also Williams v. State, 48 S.E. 938 (Ga. 1904) (refusing to convict under a nonsupport statute absent a showing that the father left his children in a destitute condition); Baldwin v. State, 45 S.E. 399 (Ga. 1903) (same).

145. Leibold v. Leibold, 62 N.E. 627,627 (Ind. 1902).

146. See, e.g., State v. Miller, 52 A. 262, 264 (Del. 1902) (awarding one dollar per week each for a 14 year-old and an 11 year-old); Steele v. People, 88 Ill. App. 186, 187 (Ct. App. 1900) (awarding two dollars per week); Parker v. Parker, 42 A. 160, 163 (N.J. Ch. 1899) (awarding eight dollars per week for a wife and a child); Harrington v. Court of Special Sessions, 15 N.Y.S. 328, 329 (N.Y. Sup. Ct. 1888) (noting that a police justice awarded six dollars per week under a disorderly person statute). The nonsupport statutes, however, did provide for prospective, ongoing awards of support. See, e.g., State ex rel. Rogers v. Rogers, 43 A. 250, 251 (Del. 1895); Keller v. Commonwealth, $71 \mathrm{~Pa} .413,417$ (1872).

147. 1884-1885 N.J. Acts ch. 2.

148. See, e.g., Ind. Rev. Stat. $\$ 2133$ (1881).

149. See, e.g., 1883 N.H. Laws ch. 58.

150. See, e.g., 1882 Mass. Acts ch. 270; 1885 Wis. Laws ch. 422.

151. See, e.g., 1882 Conn. Pub. Acts ch. 30 . This type of statute eventually became the national standard for nonsupport laws, as laws of this kind were enacted in 45 jurisdictions by 1935. See 4 CHESTER G. VERNIER, AMERICAN FAMILY LAWS $\$ 234$ at 61 (1936).

152. See May, supra note 140 , at $43-49$. 
When cases under these statutes entered the courts late in the nineteenth century, courts almost always categorized nonsupport prosecutions as criminal. ${ }^{153}$ These decisions solidified the connection between dependency and punishment by reasoning that those who caused dependency on the state needed to be punished by the criminal law. Courts justified the criminal nature of the new statutes by asserting-as had the courts inventing the common-law support obligation ${ }^{154}$ - that a nonsupporting husband violated his duty to the public to keep his wife and children from going on poor-relief. The duty of supporting a minor child, said the Supreme Court of Ohio, "is a duty which he owes to the state, as well as to his children; and he has no more right to allow them to become a public charge than he has to allow them to suffer for want of proper care and sustenance." ${ }^{155}$ The Rhode Island Supreme Court ruled that a nonsupport proceeding could go forward even though the complainant was dead. This outcome would have been unthinkable if the child support duty were merely civil. But the court held that the proceeding could continue because it was a criminal action brought by the state. "It is the peace and dignity of the state which has been violated in the commission of any crime or offense," the court said, "and hence no one but the state can, in any true sense, prosecute the offender for such a wrong." ${ }^{156}$ The "peace and dignity" of the state, in nonsupport prosecutions, was the peace of the state's relief rolls and the dignity of the state's interest in keeping its residents off public charity. The idea that desertion and nonsupport statutes punished an offender for his role in causing dependency on the state was vigorously asserted by courts interpreting the new laws. In these decisions, courts tied the dependency and punishment rationales together, completing the move to the modern American way of thinking about child support.

\section{CONCLUSION: DEPENDENCY AND PUNISHMENT IN AMERICAN CHILD SUPPORT LAW}

American courts in the nineteenth century invented a parental child support obligation in the context of increasing concerns about dependency among single mothers. Many of these courts also reasoned that child support awards served as punishments for a wrongdoing parent, a line of discourse expanded in the 1870 s and 1880 s in criminal statutes that punished nonsupport. By the early twentieth century, the principal discourses of the modern American child support system-dependency and

153. See, e.g., State v. Schweitzer, 18 A. 787 (Conn. 1889); see also State v. Miller, 52 A. 262 (Del. 1902) (holding that such proceedings are quasi-criminal).

154. See supra note 107 and accompanying text.

155. Bowen v. State, 46 N.E. 708, 709 (Ohio 1897).

156. State v. Peabody, 55 A. 323, 323 (R.I. 1903). 
punishment-were already in place. ${ }^{157}$ As was the case with the motivations of the nineteenth-century American courts and legislatures that invented a civil and criminal child support duty, the modern child support system is centrally concerned with saving public money. ${ }^{158}$ As was the case in nineteenth-century America, child support awards today continue to be quite low, often barely enough to keep a single mother and children from destitution. ${ }^{159}$ Consistent with the rhetoric of nineteenth-century courts dealing with nonsupporting fathers, "deadbeat dads" continue to be vilified in the national political discourse for their role in forcing single mothers onto welfare. ${ }^{160}$

In fact, the most significant difference between the early and modern child support systems is not in their intellectual foundations, but in their racial politics. African-American families, formerly excluded from the child support system, are now at the center of efforts to reform welfare. The racial politics of America's welfare system, in which welfare is perceived primarily as a program for young African-American women, who are demonized as "welfare queens," are well-known. ${ }^{161}$ What is less wellknown is the way in which young black men have become the unacknowledged locus of efforts to reform welfare through child support collections. Large proportions of black children are born out of wedlock, and high rates of poverty among such families have led national welfare reform debates to focus on establishing paternity and collecting child

157. See supra note 107.

158. In most states, any child support collected on behalf of a welfare recipient goes directly to the state to offset its welfare costs. See Fatherhood and Changes to the Welfare System: Hearings on H.R. 3314 Before the Subcomm. on Human Resources of the House Comm. on Ways and Means, 105th Cong. (1998) (statement of Wendell Primus, Director of Income Security, Center on Budget and Policy Priorities), available in 1998 WL 437021 (F.D.C.H.) [hereinafter Primus Testimony]. Concerns that the government spends too much on welfare have motivated almost every major reform in the modern child support system. For example, Title IV-D was added to the Social Security Act, see Pub. L. No. 94-88, 1975 U.S.C.C.A.N. (89 Stat.) 433 (codified as amended in scattered sections of 42 U.S.C.), largely because of concerns about welfare dependency caused by nonpayment of child support, see HARRY D. KRAUSE, CHILD SUPPORT IN AMERICA: THE LEGAL PERSPECTIVE 53-61 (1981). Similarly, concerns about the rates of welfare dependency among single mothers with outstanding interstate child support awards led Congress to enact the Child Support Recovery Act of 1992, Pub. L. No. 102-521, 1992 U.S.C.C.A.N. (106 Stat.) 3403 (codified as amended in scattered sections of 42 U.S.C.). See H.R. REP. No. 771, at 5 (1992).

159. See supra note 7.

160. The theme of irresponsible men who do not take responsibility for the support of their children runs throughout MARCIA MOBILIA BOUMIL \& JOEL FrIEDMAN, DEADBEAT DADS: A NATIONAL CHILD SUPPORT SCANDAL (1996), a recent book on the child support system.

161. See Fraser \& Gordon, supra note 6, at 327; Dorothy E. Roberts, Welfare and the Problem of Black Citizenship, 105 YALE L.J. 1563, 1563 (1996) (reviewing LINDA GORDON, PITIED BUT NOT ENTITLED: SINGLE MOTHERS AND THE HISTORY OF WELFARE (1994) and JILL QUADAGNo, THE COLOR OF Welfare: How RACISM UNDERMINED THE WAR ON POVERTY (1994)). 
support from black men. ${ }^{162}$ Sometimes, an emphasis on paternity establishment is coupled with a realistic assessment of the economic obstacles faced by young black men under child support orders. ${ }^{163}$ More often, commentators resort to a nineteenth-century style of blaming black men under child support orders by assuming that these men are simply unwilling to pay child support. ${ }^{164}$

This is not to say that personal responsibility has no appropriate place in the child support system. The problem with the dependency-punishment paradigm, however, is that the fathers of the children who are most likely to receive welfare are usually the least likely to be able to make regular child support payments. ${ }^{165}$ In this situation, relying exclusively on private sources of child support when it is not economically realistic for some noncustodial fathers to pay it might satisfy politicians' desires to do something about the nonpayment of child support, but it does little to ensure that children are provided with an adequate standard of living. ${ }^{166}$

In most industrialized nations, private child support payments are not a central way in which the community makes sure that children are adequately supported. Instead, most industrialized nations have some kind of child allowances financed by the public or by employers that go to all families. ${ }^{167}$ In England, for instance, families receive a universal "Child Benefit" to defray the costs of raising children; and all single-parent families receive an additional "One Parent Benefit." 168 But although the

162. See Fatherhood and Changes to the Welfare System: Hearings on H.R. 3314 Before the Subcomm. on Human Resources of the House Comm. on Ways and Means, 105th Cong. (1998) (testimony of Gordon L. Berlin, Senior Vice President, Manpower Demonstration Research Corp.), available in 1998 WL 432027 (F.D.C.H.) (describing the results of a pilot project intended to improve child support among poor fathers and noting that $80 \%$ of the study group was black or Latino); 141 CoNG. REC. S2872-73 (daily ed. Feb. 16, 1995) (statement of Sen. Bill Bradley) (discussing welfare, paternity establishment, child support collections, and race); Irwin Garfinkel et al., Child Support and Child Well-Being: What Have We Learned?, in CHILD SUPPORT AND CHIID WELL-BEING 1, 1-2 (Irwin Garfinkel et al. eds., 1994); Freya L. Sonenstein et al., Promising Approaches to Improving Paternity Establishment Rates at the Local Level, in CHILD SUPPORT AND CHILD WELL-BEING, supra, at 31, 32 .

163. See, e.g., Primus Testimony, supra note 158, available in 1998 WL 437021 (attributing the lack of child support payments to a steady decay in the wages of men with only high school diplomas over the past 20 years); 133 CONG. REC. 27,935 (1987) (stating that many black poor women do not receive child support awards because real earnings by black men declined by around 50\% from 1973 to 1984).

164. See, e.g., Work Hard and Play by the Rules, WASH. TIMES, Oct. 29, 1995, at B2 (arguing that the gap between black and white child support collections could be resolved by "a greater degree of personal and family responsibility" among black men); see also Richard Higgins, Overcome Odds, Black Men Told, BostON GLOBE, Apr. 26, 1991, at Metro/Region 1 (noting the "assumption that black males are unwilling to pay child support").

165. See JOSEPHSON, supra note 9, at 96-98.

166. See Krause, supra note 9, at 177-78.

167. See generally Jonathan BRADShaw \& David PIACHAUd, ChILD SUPPORT IN THE EUROPEAN COMMUNTTY 103-07 (1980) (outlining family allowance policies in European nations).

168. See Stein Ringen et al., Great Britain, in FAMILY CHANGE AND Fanilly POLICIES IN GREAT BRITAIN, CANADA, NEW ZEALAND AND THE UNITED STATES, supra note 12, at 31, 62-63. 
United States has generous, publicly funded benefits such as Social Security and Medicare for elderly Americans, no comparable program exists for children.

The historical account of the origins of the American child support duty in concerns about dependency and punishment allows for at least a tentative sketch of a historical argument to explain why America in the early twentieth century did not enact a system of child benefits or family allowances. When single motherhood began to emerge in nineteenthcentury America, the judiciary was the only institution of the American state that could deal with dependency among single mothers and their children: The poor laws were being overwhelmed by population growth and urbanization, and private charities and state poor-relief agencies had not yet appeared. The first child support statutes built on this judicial innovation, codifying a child support system that relied primarily on payments from absent parents, instead of on public supports for families. A privatized child support system might have been a background factor that lessened the pressure for family allowances in early-twentieth-century America. ${ }^{169}$ This system of private child support transfers and a lack of public supports for raising children remains with us today, as concerns about dependency and punishment continue to dominate the modern American child support system.

The English Child Benefit originated in the system of "Family Allowances" enacted in postwar England in response to concerns about the welfare of working-class families and the disincentives for work that had been created by unemployment insurance during the Depression. The Family Allowances were finally made possible by a new consensus around the necessity for comprehensive social services that was caused by total wartime mobilization. See SUSAN PEDERSEN, FAMILY, DEPENDENCE, AND THE ORIGINS OF THE WELFARE STATE: BRITAIN AND FRANCE, 1914-1945, at 316-36 (1993).

169. Although many American states enacted "mothers' pensions" in the early twentieth century, these pensions were not available to all mothers-married or single, divorced or widowed-but only to single, widowed mothers. See THEDA SKOCPOL, PROTECTING SOLDIERS AND MOTHERS: THE POLITICAL ORIGINS OF SOCIAL POLICY IN THE UNITED STATES 424-79 (1992). 
